\title{
Article \\ Investigating the Emission of Hazardous Chemical Substances from Mashrabiya Used for Indoor Air Quality in Hot Desert Climate
}

\author{
Chuloh Jung *(D) and Nahla Al Qassimi
}

Citation: Jung, C.; Al Qassimi, N. Investigating the Emission of Hazardous Chemical Substances from Mashrabiya Used for Indoor Air Quality in Hot Desert Climate. Sustainability 2022, 14, 2842. https:/ / doi.org/10.3390/su14052842

Academic Editor: Diego Pablo Ruiz Padillo

Received: 3 January 2022

Accepted: 14 February 2022

Published: 28 February 2022

Publisher's Note: MDPI stays neutral with regard to jurisdictional claims in published maps and institutional affiliations.

Copyright: (C) 2022 by the authors. Licensee MDPI, Basel, Switzerland. This article is an open access article distributed under the terms and conditions of the Creative Commons Attribution (CC BY) license (https:// creativecommons.org/licenses/by/ $4.0 /)$.
Department of Architecture, College of Architecture, Art and Design, Healthy and Sustainable Buildings Research Center, Ajman University, Ajman P.O. Box 346, United Arab Emirates; n.alqassimi@ajman.ac.ae

* Correspondence: c.jung@ajman.ac.ae

\begin{abstract}
Dubai has the reputation of a continuously growing city, with skyscrapers and mega residential projects. Many new residential projects with poor choices of material and ventilation have led to a faster rise in sick building syndrome (SBS) in Dubai than in any other country, and the IAQ (indoor air quality) has become more critical. Volatile organic compounds (VOCs) and formaldehyde $(\mathrm{HCHO})$ affect the health of residents, producing the phenomenon known as SBS (sick building syndrome). It has been reported that wood materials used for furniture and wooden windows and doors are a significant source of indoor air pollution in new houses. This paper aims to identify the factor elements emitting harmful chemical substances, such as VOCs and HCHO, from wooden mashrabiya (traditional Arabic window) by examining the characteristics of the raw and surface materials through test pieces. As a methodology, a small chamber system was used to test the amount of hazardous chemicals generated for each test piece. For Total volatile organic compounds (TVOC) and $\mathrm{HCHO}$, the blank concentration before the injection and the generation after seven days were measured. The results showed that to reduce TVOC, it is necessary to secure six months or more as a retention period for raw materials and surface materials. The longer the retention period, the smaller the TVOC emission amount. In the case of mashrabiya, an HCHO low-emitting adhesive and maintenance for one month or more are essential influencing factors. It was proven that using raw materials with a three-month or more retention period and surface materials with a one-month or more retention period is safe for indoor mashrabiya. This study is the first study in the Middle East to identify factors and characteristics that affect the emission of hazardous chemicals from wood composite materials, such as wood mashrabiya, that affect indoor air quality in residential projects in Dubai. It analyzes the correlation between emission levels and the retention period of raw and surface materials, in order to provide a new standard for indoor air pollutants.
\end{abstract}

Keywords: mashrabiya; total volatile organic compounds (TVOC); formaldehyde (HCHO); retention period; hot desert climate

\section{Introduction}

From the point of view of selecting building materials in the design stage of a house, it is helpful to use data on the amount of hazardous chemical substances generated from each building material [1,2]. In the case of using construction materials with a large amount of hazardous chemical substances, more ventilation is required to meet a certain concentration standard than when using low-generation building materials. In a hot desert climate, this leads to an increased energy consumption [3]. Therefore, it is desirable not only in terms of comfort and health, but also in an energy-saving aspect to use materials that generate low-toxicity substances [4].

In the United Arab Emirates (UAE), the Emirates Green Building Council launched the Energy Efficiency Program (EEP) in 2013 to reduce the carbon footprint for existing energyinefficient buildings [5]. The EEP database was launched in 2014 to facilitate building retrofit 
projects, and the Technical Guidelines for Retrofitting Existing Buildings was published in 2015 [6]. After the guidelines, Building Retrofit Training (BRT) was launched in 2017 by the Dubai Supreme Council of Energy and Masdar to increase the fundamental knowledge of retrofits specific to the MENA (Middle East/North Africa) region [6].

During this process, the recent construction of energy-efficient houses in Dubai has become more air-tight [7]. Accordingly, the importance of air quality in the indoor environment of a house is increasing [8]. In particular, it is known that indoor air pollution caused by chemicals such as volatile organic compounds (VOCs) and $\mathrm{HCHO}$ affects the health of residents [9].

According to the Dubai Healthcare City report, an estimated 15\% of Dubai residents have suffered sick building syndrome (SBS) symptoms, such as fatigue, headache, red eyes, eye/nose/throat irritation, dry cough, dry or itchy skin, dizziness, and difficulty in focusing on work [10,11]. Due to this SBS phenomenon, the Dubai Municipality initiated the indoor air quality (IAQ) concentration standards, requiring less than $0.08 \mathrm{ppm}$ (parts per million) of $\mathrm{HCHO}$, less than 300 micrograms $/ \mathrm{m}^{3}$ of total volatile organic compounds (TVOCs), and less than 150 micrograms $/ \mathrm{m}^{3}$ of particulate matter $\left(\mathrm{PM}_{10}\right)$ (less than 10 microns) in $8 \mathrm{~h}$ of continuous monitoring prior to occupancy for new houses [12].

In previous studies, it has been reported that wood materials used for furniture and wooden windows and doors are a significant source of indoor air pollution in new houses [13]. It should be noted that wood products emit hazardous chemical substances continuously for an extended time, since the emission characteristics of hazardous chemicals from wood over time are different from those of hazardous chemical substances generated from paints and adhesives [14,15].

In particular, in the case of new houses, the amount of built-in furniture is increasing [16]. As the risk of indoor contamination by hazardous chemical substances generated in wood materials during construction increases, the need for the control of this has also increased [17]. These wood products are applied indoors as a composite material, rather than a single wood product, formed by applying different surface materials, such as a particle board (PB) or medium-density fiberboard (MDF), and going through various processing methods [18]. In addition, the installation of these wood products follows a process in which partially finished products are brought into the room, with a time gap according to the process, and are installed and finished onsite [19]. Therefore, it is possible to reduce, to some extent, the natural emission of toxic chemical substances from wood materials by making adjustments to such factors as the retention period on site during the installation process [20].

Indoor wood products are molded from composite materials rather than single materials, and identifying the emission characteristics of hazardous chemical substances could be helpful in improving indoor air quality [21,22].

Currently, wood materials mainly used for new houses in Dubai can be classified into mashrabiya (Figure 1) and built-in furniture materials.

The influencing factors can be derived by reviewing the previous literature on the emission characteristics of hazardous chemical substances from single materials or composite materials from furniture and wooden windows/doors.

Several researchers have conducted research on the emission characteristics of chemical substances emitted from wood materials, such as furniture and wooden windows/doors [23]. Adamová et al. (2020) [24] and Ulker et al. (2021) [25] report that, unlike the emission process of paints or adhesives, chemicals in wood materials are continuously emitted into the air in trace amounts for a very long time. Their research focuses on single materials such as plywood, $\mathrm{PB}$, and MDF.

Richter et al. (2021) [26] reports the effect of a single material combination on the emission of pollutants from composite finishing materials, since the building finishing materials mainly used in houses are composite finishing materials. For the composition of the test piece, a composite material composed of wallpaper and adhesive or floorboard and adhesive was used in the experiment. The release mechanism was estimated based 
on the results showing the difference in the emission amount of the composite material according to the difference in the contaminant content of the single material constituting the composite material. The amount of composite materials emitted differs depending on the composition of the single material and the degree of contamination.

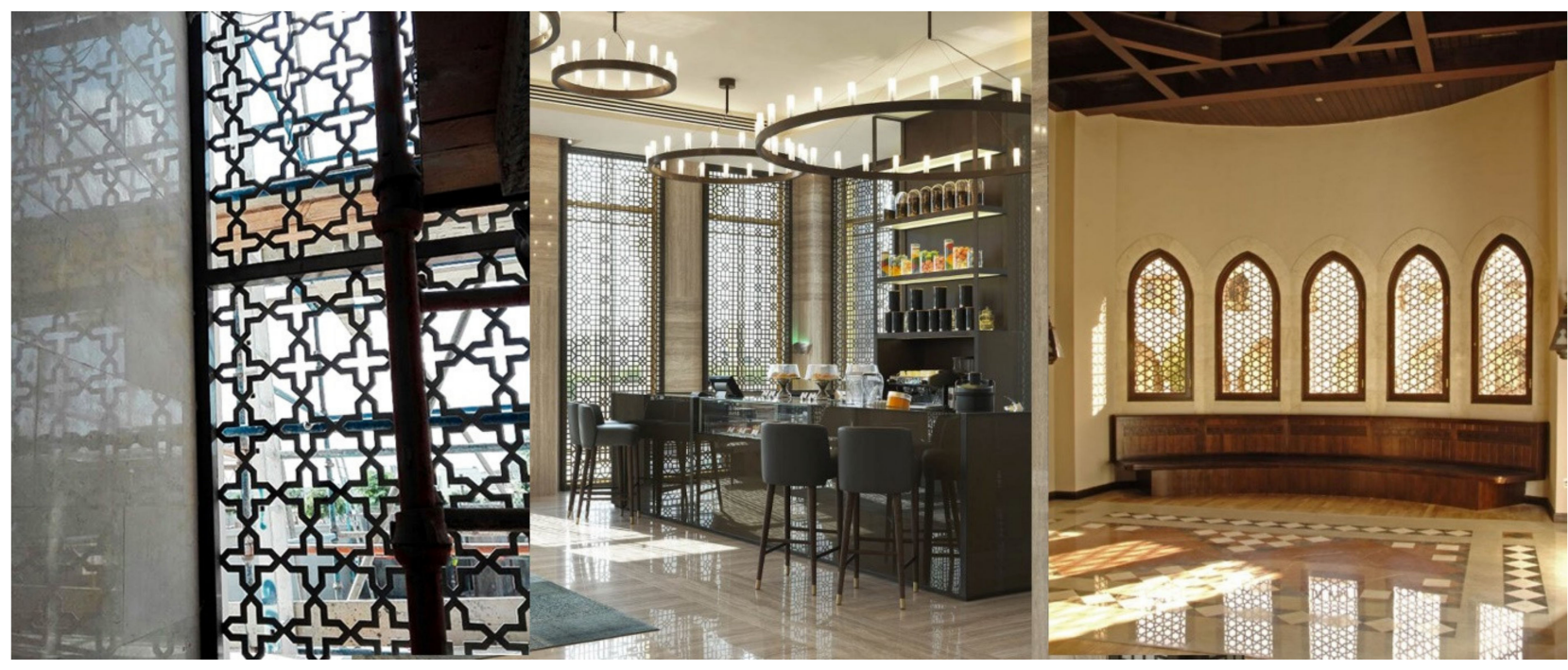

Figure 1. Wooden mashrabiya window at Dubai Hill Estate.

Cao et al. (2019) [27] reports that MDF is treated with low-pressure melamineimpregnated paper (LPM), which is a surface method for furniture materials, on both sides, and those that were not treated were targeted. The experiment was carried out with differences in the exposure of the cut surface in the case of the MDF-treated material on both sides. As a result, the emission intensity tended to increase as the ratio of the cut surface increased (the surface finish area decreased). It was reported that most of the wood materials showed a difference in the amount of emission depending on the surface finishing method.

Qi et al. (2019) [28] produced six types of built-in furniture by selecting furniture composed of raw materials and surface finishing materials commonly used in apartments and identified the chemical pollutant emission characteristics by raw material grade and surface finish. This study reported that the concentration of $\mathrm{HCHO}$ was different depending on the core material in the same surface finishing material.

Xiong et al. (2019) [29] reports that the emission of TVOC is not affected by the grade of the core material, but is affected by the finish of the surface material. In the TVOC case, the raw material grade influences and the difference in the quantity of emission by the surface material were established.

Through the above literature review, in the case of a wood composite finishing material, very diverse factors affect the emission of hazardous chemical substances. The degree of contamination of single raw materials or surface materials, differences in surface finishing methods, and the retention period of raw materials constituting composite finishing materials were identified as factors affecting the release of hazardous chemical substances [30].

The purpose of this study is to identify the factors emitting harmful chemical substances from wooden mashrabiya by examining the characteristics of the raw materials and surface finishing materials of the test pieces.

\section{Materials and Methods}

\subsection{Types and Characteristics of Raw Materials}

\subsubsection{Fiberboard}

Fiberboard is a generic term for plate products formed by fiberizing wood or other plants and is classified according to density [31]. Since fiberboard has a dense structure and 
excellent machinability, it can be used instead of general wood for construction sites that require precise dimensions or for frames and moldings that require accurate angles [32]. The Environmental Protection Agency (EPA) in the United States has classified the above materials according to the amount of HCHO emission since 2018 [33] (Table 1).

Table 1. Classification of fiberboards and EPA HCHO emission standards.

\begin{tabular}{ccc}
\hline Types & Density & EPA HCHO Emission Standards \\
\hline $\begin{array}{c}\text { Hard Fiberboard (HB) } \\
\text { - Veneer Core }\end{array}$ & More than $0.85 \mathrm{~g} / \mathrm{cm}^{3}$ & $0.05 \mathrm{ppm}$ \\
\hline $\begin{array}{c}\text { HB } \\
\text { - Composite Core }\end{array}$ & & \\
\hline $\begin{array}{c}\text { Medium-Density Fiberboard } \\
\text { (MDF) }\end{array}$ & $0.35 \mathrm{~g} / \mathrm{cm}^{3}-0.85 \mathrm{~g} / \mathrm{cm}^{3}$ & $0.11 \mathrm{ppm}$ \\
\hline
\end{tabular}

It is classified as MDF with a density of less than $0.35 \mathrm{~g} / \mathrm{cm}^{3}-0.85 \mathrm{~g} / \mathrm{cm}^{3}$, and $\mathrm{HB}$ with a density of $0.85 \mathrm{~g} / \mathrm{cm}^{3}$ or more. MDF is the most used and can be produced from $3.0 \mathrm{~mm}$ to $30 \mathrm{~mm}$ thick [34] (Figure 2).

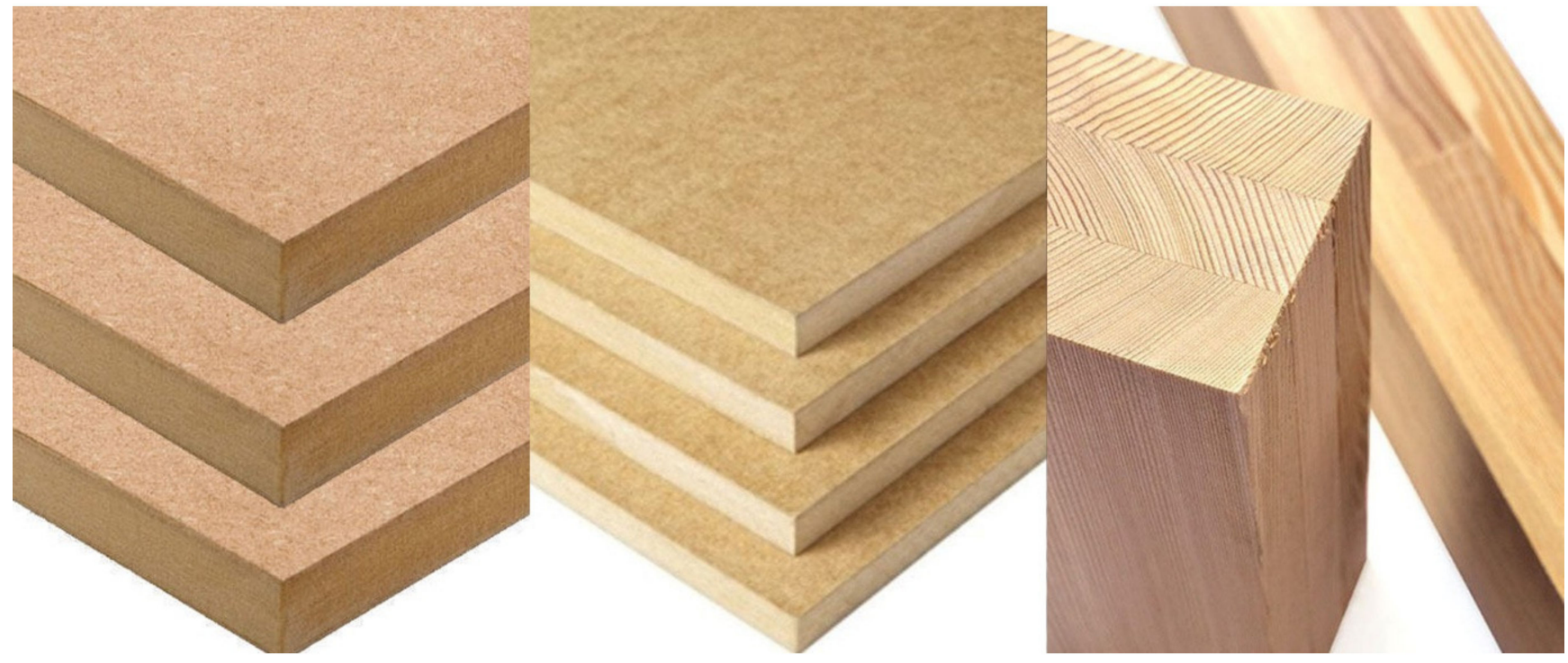

Figure 2. HB (left), MDF (middle), and glued laminated timber (right).

\subsubsection{Glued Laminated Timber}

Glued laminated timber refers to a material that is laminated and adhered in the length, width, and thickness directions by paralleling each other in the fiber direction using sawmills, boards, or small square materials [35] (Figure 2). Additionally, it refers to a material that is decorated on the surface of the aggregated material for aesthetics.

Dissimilar to plywood by orthogonal and odd-sheet lamination methods, glued laminated timber is not manufactured in a plate shape, and it is manufactured in various shapes and sizes depending on the purpose of use. It is mainly used as a wooden frame material for windows and doors and as a core material for doors, and one of the most popular glued laminated timbers is Lauan laminated timber (LLT).

\subsection{Types and Characteristics of Surface Finishes}

\subsubsection{Veneer}

Veneer refers to a product manufactured by processing raw wood as thin as paper [36]. It is used as a decorative material to express the naturalness and splendor of wood. It is a material that can express the texture of wood by finishing the primary structural frame with 
gypsum board or plywood, applying adhesive to the surface, and attaching it by heating and pressing methods [37]. In most cases, it is usually composed of a thin plate of $0.2 \mathrm{~mm}$, and it is rarely used as an exterior material.

For the sample used in this experiment, samples prepared by wrapping veneer around raw materials of LLT, MDF, and HB, used for mashrabiya, were used with hot-melt-type adhesive [38].

\subsubsection{Polyvinylchloride (PVC) Sheet}

PVC sheet is manufactured by mixing polyvinyl chloride as a raw material with stabilizer, plasticizer, and pigment [39]. Since it is easy to process and mass production is possible, it is currently widely used as a surface material for overlay or wrapping of interior materials, furniture, and wooden windows and doors.

For the sample used in this experiment, a sample piece wrapped around PB was used with a water-based liquid adhesive.

\subsubsection{Finishing Foil (F/F)}

It is a patterned paper in which paper is impregnated with thermosetting resin (melamine, urea, and acrylic), and then the surface is painted [40]. This material was developed to reduce the cost of LPM. Dissimilar to LPM, an additional adhesive must be used to bond the finishing foil. In the Middle East, it is commonly used as an interior building material and furniture surface finishing material [41].

For the sample used in this experiment, the sample was wrapped in raw materials of LLT, MDF, and HB, and the finishing foil with a hot-melt adhesive precoated on the backside was used.

\subsection{Hazardous Chemical Emission Test Method for Mashrabiya}

\subsubsection{Test Piece Overview}

The test piece used in this experiment was from the same composite material in the interior of the Dubai Hill house [42]. The raw materials, adhesives, and surface materials of actual mashrabiya in Dubai Hill were used. Figure 3 shows the configuration of the test piece. It was composed of a surface finishing method of wrapping using an adhesive between the raw and surface materials.

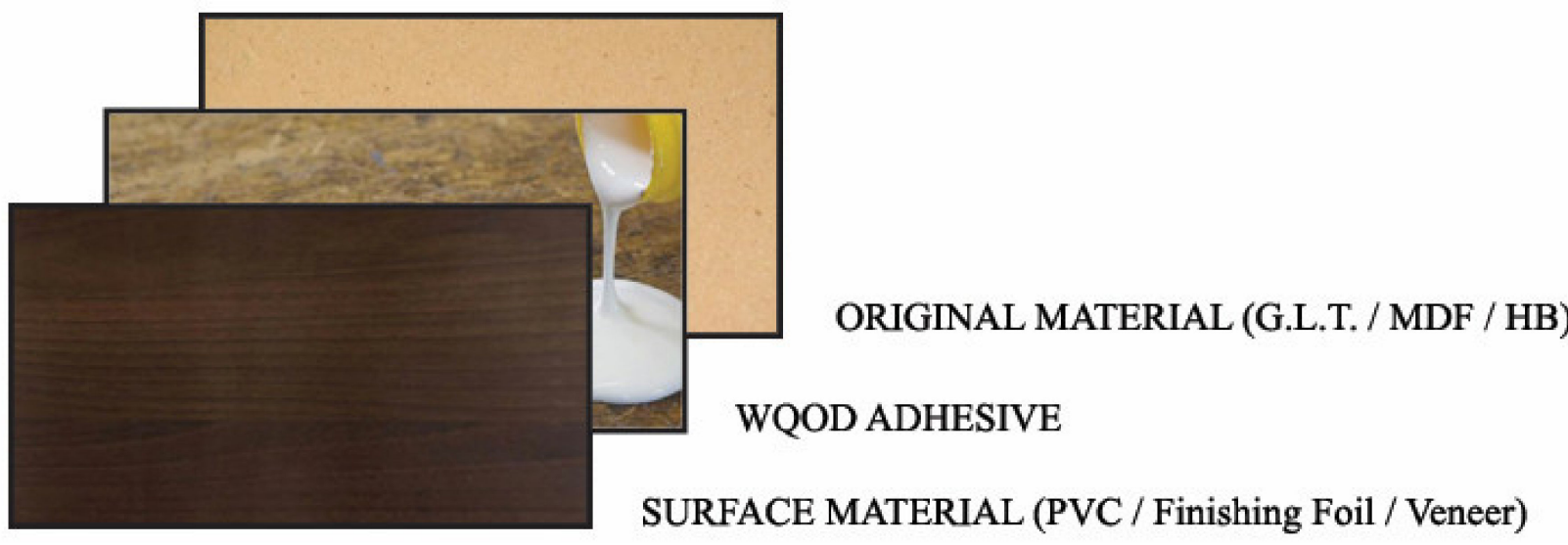

Figure 3. Material composition of the test piece.

Table 2 shows the classification of test pieces according to the composition of raw materials, adhesives, surface materials of the test pieces, the production date of the test pieces, and the test start date after standing for a certain time.

Among the test specimens, in the case of test pieces TP-01, TP-02, and TP-03, PVC, $\mathrm{F} / \mathrm{F}$, and veneer were wrapped in LLT, using materials of traditional style mashrabiya, and PVC, F/F, and veneer were wrapped in MDF and $\mathrm{HB}$, respectively. The test pieces of TP-04, TP-05, TP-06, TP-07, TP-08, and TP-09 were manufactured assuming the material of laser-cut mashrabiya [43]. 
Table 2. Test piece composition and production/test start date.

\begin{tabular}{cccc}
\hline Name & Material Composition for Test Piece & Production Date & Test Start Date \\
\hline TP-01 & LLT + Wood Adhesive + PVC & $04 / 09 / 2021$ & $28 / 09 / 2021$ \\
\hline TP-02 & LLT + Wood Adhesive + F/F & $04 / 09 / 2021$ & $28 / 09 / 2021$ \\
\hline TP-03 & LLT + Wood Adhesive + Veneer & $04 / 09 / 2021$ & $28 / 09 / 2021$ \\
\hline TP-04 & MDF + Wood Adhesive + PVC & $04 / 10 / 2021$ & $12 / 10 / 2021$ \\
\hline TP-05 & MDF + Wood Adhesive + F/F & $04 / 10 / 2021$ & $12 / 10 / 2021$ \\
\hline TP-06 & MDF + Wood Adhesive + Veneer & $04 / 10 / 2021$ & $12 / 10 / 2021$ \\
\hline TP-07 & HB + Wood Adhesive + PVC & $02 / 11 / 2021$ & $05 / 11 / 2021$ \\
\hline TP-08 & HB + Wood Adhesive + F/F & $02 / 11 / 2021$ & $05 / 11 / 2021$ \\
\hline TP-09 & HB + Wood Adhesive + Veneer & $02 / 11 / 2021$ & $05 / 11 / 2021$ \\
\hline
\end{tabular}

Table 3 shows the composition of each test piece manufactured with the difference between the different retention periods of raw materials and surface materials [44]. For the composition of the test piece, PVC sheet, F/F, and veneer were processed for LLT, MDF, and $\mathrm{HB}$, each having a different retention period, respectively. In the case of raw materials, three-month-old LLT, six-month-old MDF, and HB were used, and in the case of surface materials, 30-75-day-old F/F, veneer, and PVC were used. In addition, all 9 test pieces had different retention periods. The retention period after production refers to the time elapsed before being used for testing after completing the production of materials with different retention periods of raw materials and surface materials by different processing methods. Specific test samples were required because, in general, when a factory product is brought into the construction field, its usual retention period is 10 to 30 days. In particular, in the case of 500 households or more, after installation, the retention time of one month is required. Therefore, to secure the emission data of furniture material considering the effect of the actual indoor air environment, the factor of the retention period after production should be considered.

Table 3. Test piece composition according to the retention period of raw materials.

\begin{tabular}{|c|c|c|c|c|c|}
\hline \multirow{2}{*}{$\begin{array}{l}\text { Surface } \\
\text { Material }\end{array}$} & \multirow{2}{*}{$\begin{array}{c}\text { Raw Material } \\
\text { Retention Period (Days) }\end{array}$} & \multirow{2}{*}{$\begin{array}{c}\text { LLT } \\
90\end{array}$} & \multirow{2}{*}{$\begin{array}{c}\text { MDF } \\
180\end{array}$} & \multirow{2}{*}{$\begin{array}{l}\text { HB } \\
180\end{array}$} & \multirow{2}{*}{$\begin{array}{l}\text { Test Piece Retention Period } \\
\text { after Production (Days) }\end{array}$} \\
\hline & & & & & \\
\hline \multirow{3}{*}{ PVC } & 30 & TP-01 & & & 14 \\
\hline & 45 & & TP-04 & & 8 \\
\hline & 70 & & & TP-07 & 3 \\
\hline \multirow{3}{*}{$\mathrm{F} / \mathrm{F}$} & 30 & TP-02 & & & 14 \\
\hline & 45 & & TP-05 & & 8 \\
\hline & 70 & & & TP-08 & 3 \\
\hline \multirow{3}{*}{ Veneer } & 30 & TP-03 & & & 14 \\
\hline & 45 & & TP-06 & & 8 \\
\hline & 70 & & & TP-09 & 3 \\
\hline
\end{tabular}

In this experiment, the retention period after production for 3, 6, and 14 days was used proportionally to create the same environment as in the construction field.

The manufacturing process of the test piece used in this experiment was the same as the manufacturing process for the villa construction [45].

It was manufactured with raw materials that passed the same process as the production period of mashrabiya, which was installed in the villa, and kept at room temperature [46]. 


\subsubsection{Experiment Conditions and Calculation of Emission Intensity}

A small chamber system according to the International Organization for Standardization (ISO) 16,000 was used to test the amount of hazardous chemicals generated by each test piece [47]. The blank concentration of seven days before injecting the sample into the chamber and the quantity of generation after injecting the sample were assessed for TVOC and $\mathrm{HCHO}$ [48]. The chamber's indoor air conditions were maintained at $25^{\circ} \mathrm{C}$ of the temperature, $50 \%$ of humidity, and 0.5 times/hour the number of ventilation. The area of the test piece was $0.044 \mathrm{~m}^{2}$, and the sample load rate was $2.2 \mathrm{~m}^{2} / \mathrm{m}^{3}$. Emission intensity was calculated according to ISO 10580.

\subsubsection{Sample Collection and Analysis Methods}

For the collection of VOCs, an adsorption tube filled with Tenax TA $200 \mathrm{mg}$ was connected to a flow sampling pump to collect a total of $3.5 \mathrm{~L}$ of air in the chamber at $167 \mathrm{~mL} / \mathrm{min}$, since Tenax TA is a widespread polymer sorbent recommended for retaining VOCs according to ISO 16000-6. The absorption procedure was as follows: VOCs were collected on the Tenax TA sorbent tube by pulling an air sample across the sorbent bed with the aid of a portable mechanical pump. VOCs were thermally desorbed from the sorbent tube within the split/splitless injection port of a GC and focused onto the head of a capillary column. GC analysis with negative ion chemical ionization MS allowed the quantification of desorbed VOCs.

To analyze the VOCs and target substances contained in standard samples and test pieces, ATD-400 (PerkinElmer, Waltham, MA, USA) directly connected to the GC column by GC/MS (gas chromatography/mass spectrometry, Agilent 6890/5973N, Santa Clara, CA, USA) was used. The analysis conditions of GC/MS were an HP-1 capillary column. The column flow was $1 \mathrm{~mL} / \mathrm{min}$, and the column temperature rate reached $60{ }^{\circ} \mathrm{C}$ within $5 \mathrm{~min}$, and, thereafter, it was allowed to rise to $260^{\circ} \mathrm{C}$ by $5{ }^{\circ} \mathrm{C}$ every $5 \mathrm{~min}$. The ion source temperature of MS was set to $260^{\circ} \mathrm{C}$ and used for analysis (Table 4).

Table 4. Overview of measuring instruments.

\begin{tabular}{|c|c|c|}
\hline Measuring Items & Measuring Instruments & Measurement Range/Accuracy \\
\hline VOCs & $\begin{array}{l}\text { - Gas Chromatograph (Agilent } 6890 \text { GC, } \\
\text { Santa Clara, CA, USA) } \\
\text { Mass Spectrometer (Agilent 5973N } \\
\text { MSD, Santa Clara, CA, USA) }\end{array}$ & $\begin{array}{ll}\text { - } & \text { Pressure sensors accuracy: } \pm 2 \% \text { full scale } \\
\text { - } & \text { Repeatability: } \pm 0.05 \text { psi } \\
\text { - } & \text { Temperature coefficient: } \pm 0.01 \mathrm{psi} /{ }^{\circ} \mathrm{C} \\
\text { - } & \text { Flow sensors accuracy: }< \pm 5 \% \\
\text { - } & \text { Repeatability: } \pm 0.35 \% \text { of setpoint } \\
\text { - } & \text { Temperature coefficient: } \pm 0.20 \mathrm{~mL} / \mathrm{min} \\
& \text { normalized temperature }\end{array}$ \\
\hline $\mathrm{HCHO}$ & $\begin{array}{l}\text { - } \quad \text { High-Performance Liquid } \\
\text { Chromatography (Shimadzu 10AVP } \\
\text { Series HPLC System, Kyoto, Japan) }\end{array}$ & $\begin{array}{ll}\text { - } & 0.01-51,200 \mu \mathrm{S} \mathrm{cm}-1 \mathrm{FS} \\
\text { - } & 0.01,0.1,1,10,100 \mu \mathrm{S} \mathrm{cm} \mathrm{cm}^{-1} / \mathrm{mV}\end{array}$ \\
\hline $\begin{array}{l}\text { Room Temperature } \\
\text { Relative Humidity }\end{array}$ & $\begin{array}{l}\text { - Digital Thermo-Hygrometer (TR-72U, } \\
\text { Taipei, Taiwan) }\end{array}$ & $\begin{array}{ll}\text { - } & -20 \text { to } 80{ }^{\circ} \mathrm{C}, 10 \text { to } 95 \% \mathrm{RH} \\
\text { - } & \text { Average }+/-0.3{ }^{\circ} \mathrm{C}\left(-20 \text { to } 80{ }^{\circ} \mathrm{C}\right) \\
\text { - } & \text { Average }+/-5 \% \mathrm{RH}\left(\text { At } 25^{\circ} \mathrm{C} 50 \% \mathrm{RH}\right)\end{array}$ \\
\hline
\end{tabular}

HCHO was collected using an LpDNPH S10L cartridge (Supelco Inc., Bellefonte, PA, USA) to collect carbonyl compounds. The sample was collected by connecting it to a flow sampling pump to remove the interference caused by ozone $\left(\mathrm{O}_{3}\right)$, and an $\mathrm{O}_{3}$ scrubber was connected in front of the LpDNPH S10L cartridge.

At this time, a total of $7.0 \mathrm{~L}$ of air was collected in the chamber at $167 \mathrm{~mL} / \mathrm{min}$, and the collected samples were stored in a cool and dark place until extraction. For the extraction of the analytical sample, the DNPH-carbonyl derivative formed by reacting with DNPH was 
extracted with $5 \mathrm{~mL}$ of HPLC-grade acetonitrile, and analysis was performed immediately. The analysis for $\mathrm{HCHO}$ was performed using high-performance liquid chromatography (HPLC, Shimadzu, Kyoto, Japan) and fixed at a maximum wavelength of $360 \mathrm{~nm}$.

\section{Results}

In this experiment, the difference in the emission amount was analyzed for composite material test pieces. The characteristics of the emission quantity due to changes in the raw material and surface material properties, and the retention duration after molding, were investigated. In addition, to understand the emission level of hazardous chemicals emitted from these test pieces, they was compared and evaluated using the Environmental Product Declaration (EPD) standard in Dubai [49].

A total of nine test pieces, prepared by the finishing method of wrapping PVC sheets, $\mathrm{F} / \mathrm{F}$, and veneer surface materials around raw materials of HB, MDF, and LLT, were used. Figures 4 and 7 show the results of the emission for TVOC and HCHO from three different test pieces, such as TP-01 using a PVC sheet with a retention period of 30 days in LLT with a retention period of 3 months, TP-04 using a PVC sheet on 45-day-old MDF with a 6-month retention period, and TP-07 using a PVC sheet with a retention period of 70 days in $\mathrm{HB}$ with a retention period of 6 months.

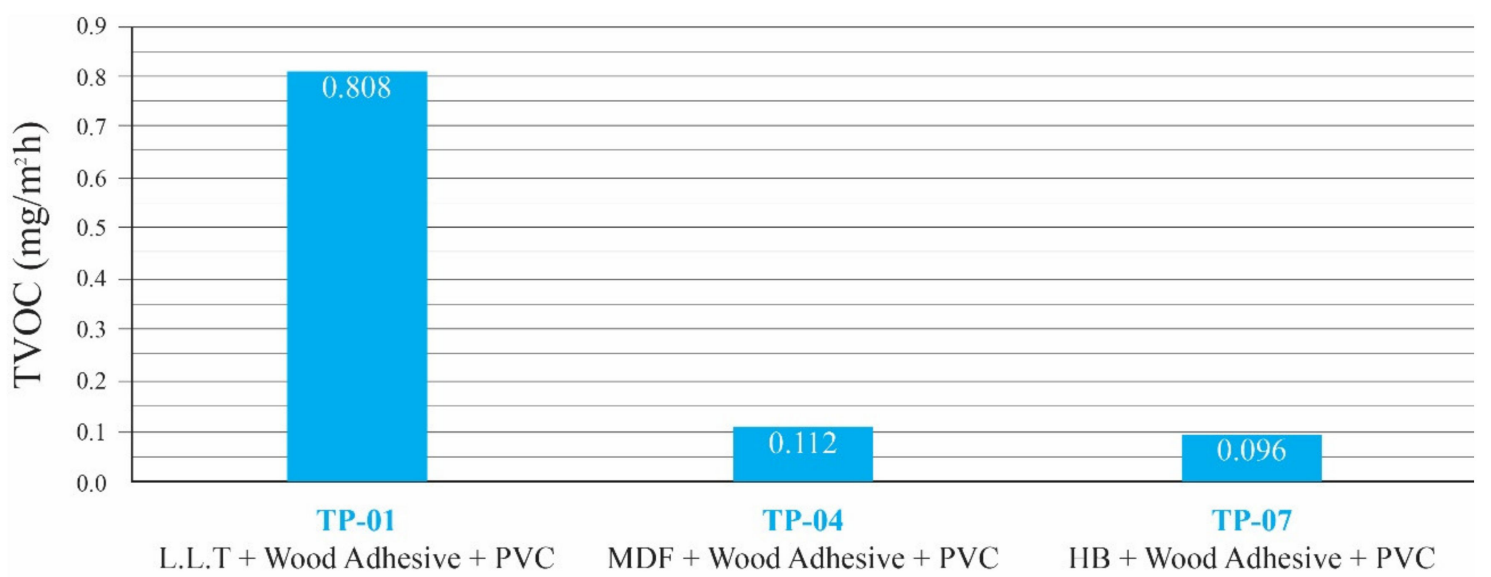

Figure 4. TVOC emission of PVC-wrapped test pieces.

Figures 5 and 8 show the results of the emission for TVOC and HCHO from three different test pieces, such as TP-02 using F/F sheets with a retention period of 30 days in LLT with a retention period of 3 months, TP- 05 using F/F sheets on 45-day-old MDF with a retention period of 6 months, and TP- 08 using F/F sheets with a retention period of 70 days in $\mathrm{HB}$ with a retention period of 6 months.

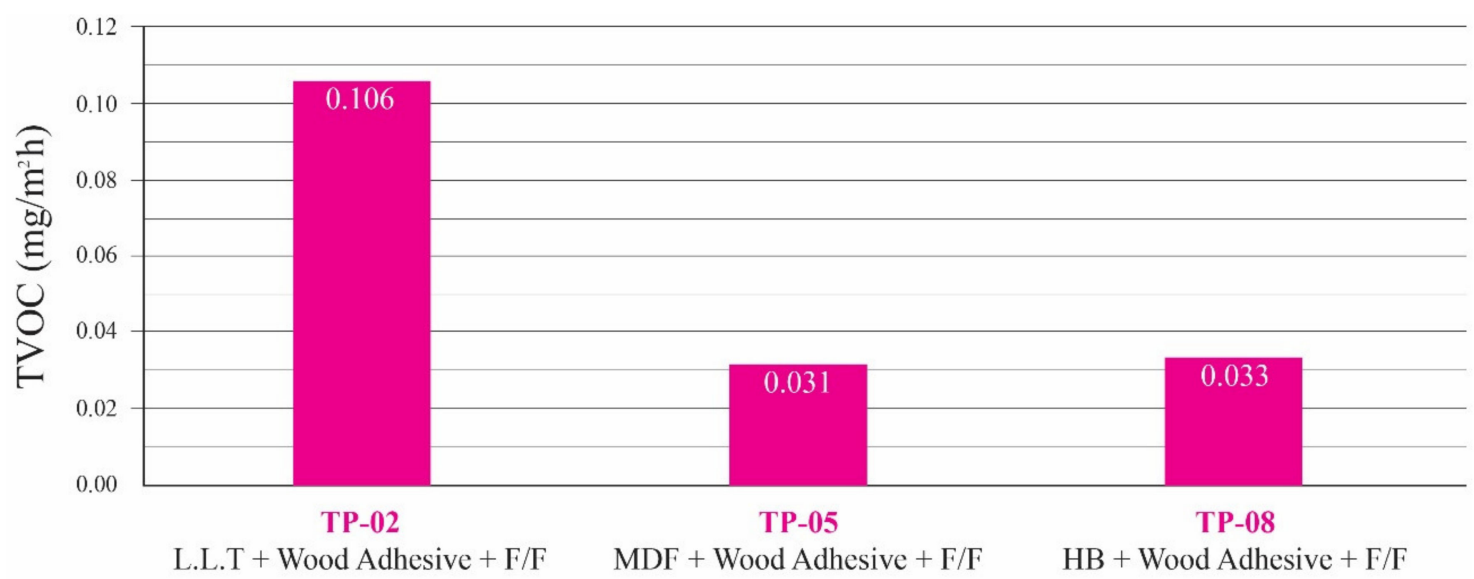

Figure 5. TVOC emission of F/F-wrapped test pieces. 
Additionally, Figures 6 and 9 show the results of the emission for TVOC and HCHO from three different test pieces, such as TP-03 using veneer with a retention period of 30 days on an LLT with a retention period of 3 months, TP-06 using veneer on MDF aged for 45 days with a retention period of 6 months, and TP-09 using veneer with a retention period of 70 days in $\mathrm{HB}$ with a retention period of 6 months.

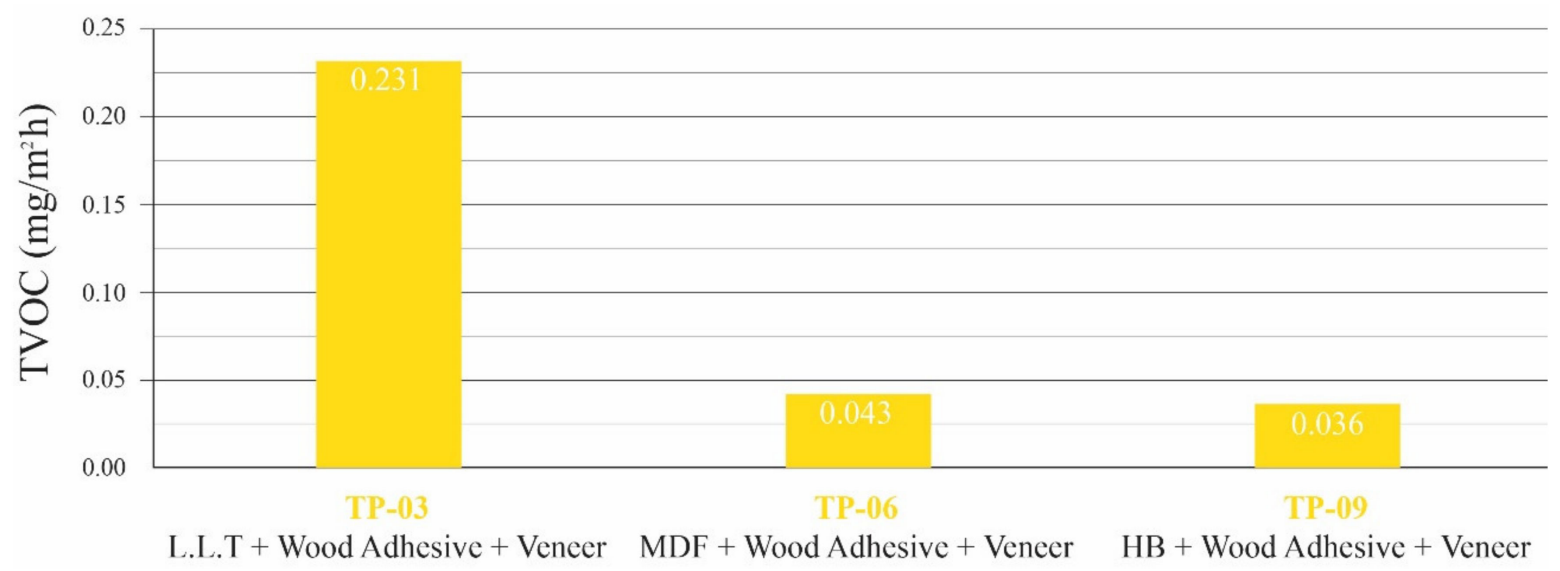

Figure 6. TVOC emission of veneer-wrapped test pieces.

First of all, it was a characteristic of the degree of contamination of raw materials and surface materials. As for raw materials, MDF and HB used the same grade of formaldehydedissipating raw materials. However, as LLT is currently excluded from classification in the EPD standards, it had the prerequisite that the degree of emission was uncertain.

\subsection{The Characteristics of TVOC Emission}

3.1.1. Emission Characteristics Due to Differences in Raw Materials and Surface Materials

Figure 4 shows the emission of TVOC for the specimens composed of different types of raw materials when the PVC sheet had the same finish. It was found that TP-01 using LLT raw materials showed a significantly higher emission than TP-04, which was MDF, and TP-07, which was HB. This trend was also shown in Figures 6 and 7. Therefore, to identify the cause of the difference in the emission, the effect of the characteristics of raw materials and surface materials was analyzed.

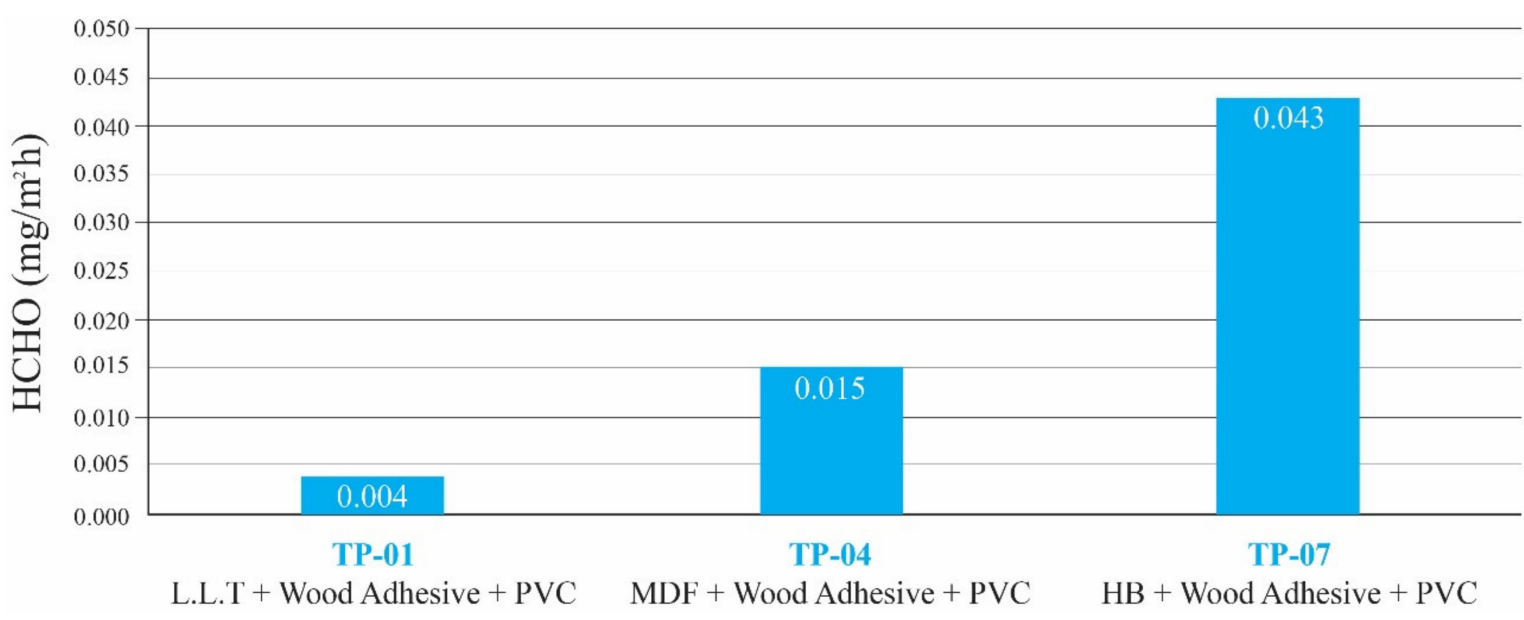

Figure 7. HCHO emission of PVC-wrapped test pieces.

In the case of the surface material, as described above in Section 2.1, the PVC sheet emitted more TVOC than the veneer and F/F. In the case of adhesives, most of the adhesives were environmentally friendly hot-melt-based or water-based. 
In order to understand the emission characteristics due to differences in surface materials, different surface materials with the same retention period of 30 days in the same LLT, PVC sheet (Figure 4, TP-01), and F/F (Figure 5, TP-02) were compared with the case finished with veneer (Figure 6, TP-03). PVC showed the highest emission at $0.808 \mathrm{mg} / \mathrm{m}^{2} \mathrm{~h}$. In the case of veneer and F/F, the emission amounts were $0.231 \mathrm{mg} / \mathrm{m}^{2} \mathrm{~h}$ and $0.106 \mathrm{mg} / \mathrm{m}^{2} \mathrm{~h}$, respectively, showing a slight difference. Additionally, to show the same trend, the raw materials of MDF were dried with different surface materials with the same retention period of 45 days, such as the PVC sheet (Figure 4, TP-04), F/F (Figure 5, TP-05), and veneer (Figure 6, TP-06). The same trend was also observed in the case of using different surface materials that had passed the same 70 days for the raw materials of $\mathrm{HB}$, such as the PVC sheet (Figure 4, TP-07), F/F (Figure 5, TP-08), and veneer (Figure 6, TP-09)

As a result of comparing and analyzing the TVOC emission in the case of finishing with different finishing materials that passed the same time on the same raw material, the difference due to the type of surface material was shown. The case of finishing with a PVC sheet showed a relatively high level, and F/F and veneer showed almost a slight difference and were detected to be low. It was judged that these results had a relatively significant effect on the type of surface material.

In what follows, we compared and evaluated the difference in the amount of emission for the retention period among the characteristics of raw materials and surface materials. In the case of raw materials in Figure 4, LLT (TP-01), which had a retention period of 3 months after production, showed a higher emission than MDF (TP-04) and HB (TP-07), which had a retention period of 6 months. In particular, PVC, which was the same surface material, was used, but by using sheets that passed 30 days for LLT, 45 days for MDF, and 70 days for HB, the PVC sheets applied to MDF and HB had a more extended retention period than LLT.

Therefore, the TVOC emission was affected by the difference between the retention periods of raw materials as the MDF+PVC and $\mathrm{HB}+\mathrm{PVC}$ test pieces with relatively long retention periods of raw materials and surface materials were significantly lower than those of LLT+PVC with short retention periods. In addition, in the case of $\mathrm{HB}+\mathrm{PVC}$ and $\mathrm{MDF}+\mathrm{PVC}, \mathrm{HB}$ and MDF raw materials had the same retention period, but the retention period of the surface material PVC had a difference of more than one month. When raw materials with a relatively long retention period of 6 months or more were used, the effect on the retention period of the surface material was judged to be weak. The same trend was observed in the test pieces finished with F/F and veneer (Figures 5 and 6).

\subsubsection{Emission Characteristics Due to Differences in Retention Period}

As shown in Table 3, the retention period of the test pieces was 14 days for the LLT+PVC (TP-01), LLT+F/F (TP-02), and LLT+veneer (TP-03) composites, eight days for the MDF+PVC (TP-04), MDF+F/F (TP-05), MDF+veneer (TP-06) composites, and three days for the HB+PVC (TP-07), HB+F/F (TP-08), HB+veneer (TP-09) composites. The characteristics of TVOC emissions were identified by classifying them into composites with different elapsed days.

Concerning Figure 4, the TVOC release was observed for the test piece of LLT+PVC (Figure 4, TP-01), which had an retention period after molding (14 days), compared to MDF+PVC (Figure 4, TP-04), with a relatively short retention period after molding, and $\mathrm{HB}+\mathrm{PVC}$ (Figure 4, TP-07) was found to be higher than that of the specimen. The results shown in Figures 5 and 6 were also the same, and it was confirmed that the samples of LLT+ F/F (Figure 5, TP-02) and LLT and veneer (Figure 6, TP-03) showed high levels. In addition, it can be seen that the case where the retention period was short for eight days and three days did not show a clear difference, and showed a relatively low release amount compared to the case of fourteen days.

It was analyzed that the effect of TVOC emission from the composite material on the retention period after molding was small. TVOC emission had little effect on the retention period due to the component characteristics of the molding material, the adhesive with $\mathrm{HCHO}$. 


\subsection{The Characteristics of HCHO Emission}

3.2.1. Emission Characteristics Due to Differences in Raw Materials and Surface Materials

As shown in Figure 7, the difference in the amount of $\mathrm{HCHO}$ emitted between the test pieces was visible, and Figures 8 and 9 also showed the same trend. In order to find out the factors that indicated the difference in the amount of $\mathrm{HCHO}$ emitted by each test piece, the effects of the characteristics of raw materials and surface materials were analyzed.

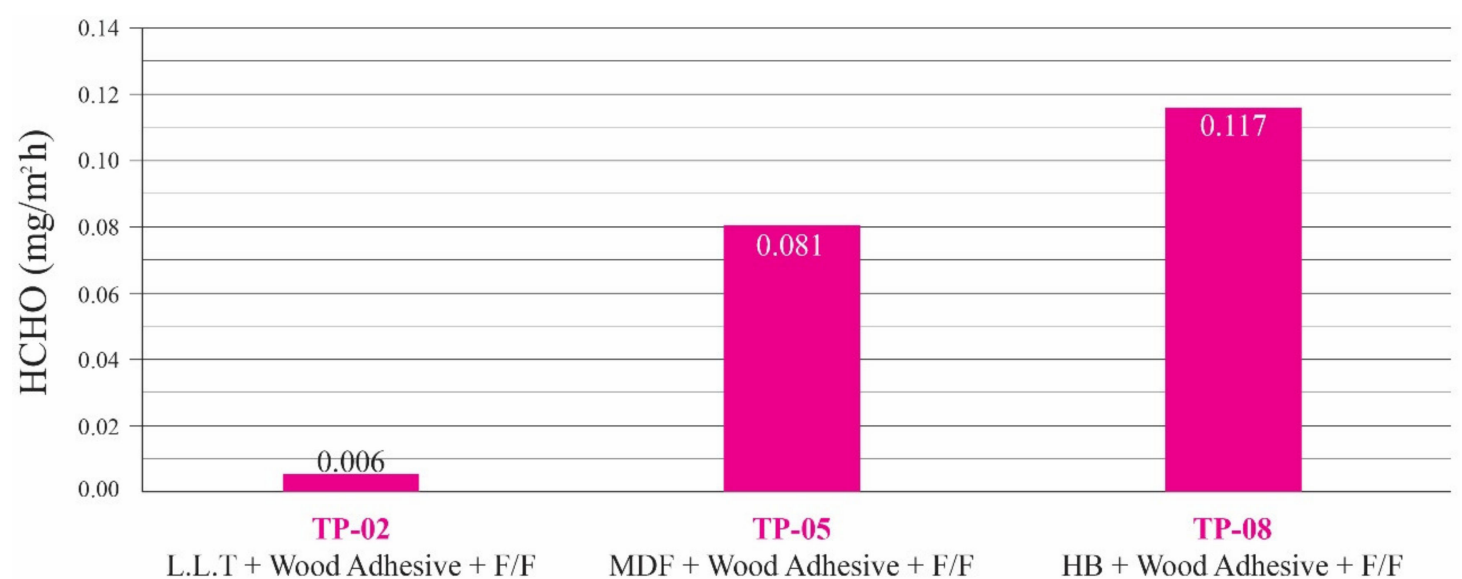

Figure 8. HCHO emission of F/F-wrapped test pieces.

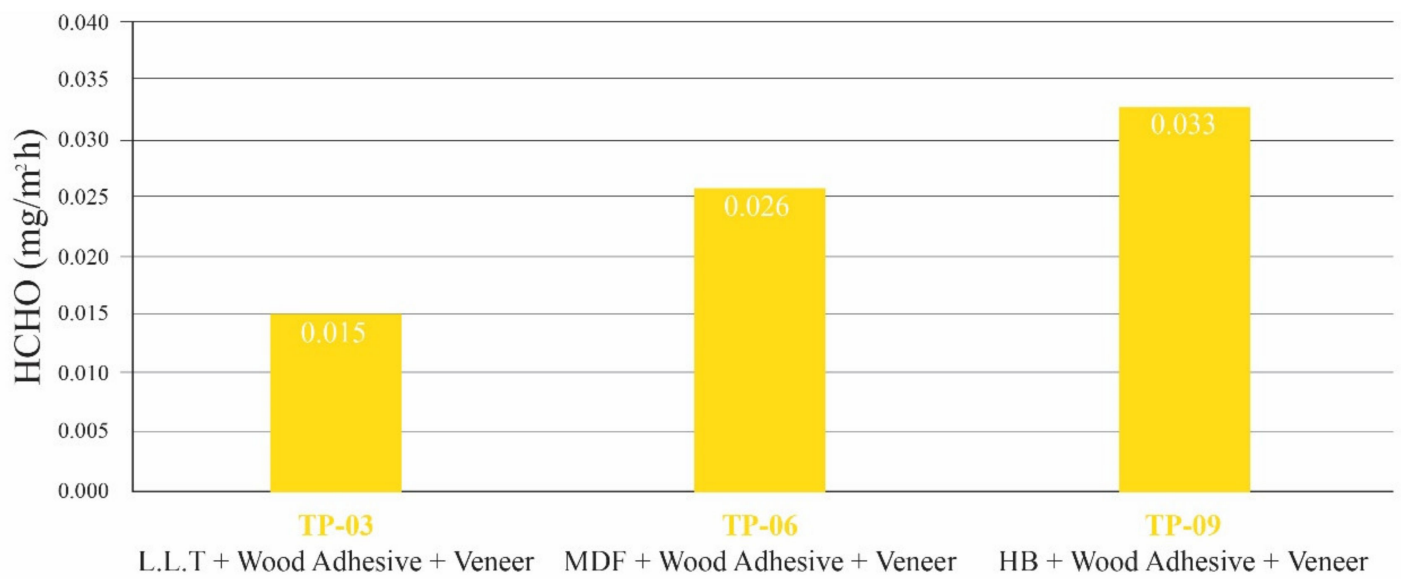

Figure 9. HCHO emission of veneer-wrapped test pieces.

The degree of contamination by raw materials, surface materials, and adhesives constituting the composite material test piece was the same as described above. On the premise of this, as shown in Figure 7, when the same surface material was applied to different raw materials, it was confirmed that the emission amount differed depending on the type of raw material. Figures 8 and 9 also showed the same trend, confirming a difference in the amount of emission depending on the type of raw material. However, it cannot be concluded that this result was a difference in the type of raw material, because it showed a significant difference in the emission amount even in the case of MDF and HB with the same $\mathrm{HCHO}$ emission grade. As can be seen from Figures 8 and 9, this trend was the same in all cases.

Meanwhile, the PVC sheets with different surface materials (Figure 7, TP-01), F/F (Figure 8, TP-02), and veneer (Figure 9, TP-03) had the same retention period of 30 days in the same LLT. In comparison, the PVC sheet showed $0.004 \mathrm{mg} / \mathrm{m}^{2} \mathrm{~h}, \mathrm{~F} / \mathrm{F} 0.006 \mathrm{mg} / \mathrm{m}^{2} \mathrm{~h}$, and veneer $0.015 \mathrm{mg} / \mathrm{m}^{2} \mathrm{~h}$, indicating that veneer showed a relatively high emission.

However, when applying different surface materials with 45 days elapsed to the same MDF and applying the same 70 days elapsed surface material to $\mathrm{HB}$, the previous case was 
veneer, whereas F/F had a relatively high emission. Although it was possible to confirm the difference in the amount of emission depending on the surface material, it was judged that there was no general trend limited to a specific surface material.

The following compared and analyzed the characteristics of $\mathrm{HCHO}$ emission for the retention period of raw materials and surface materials. As shown in Figure 7, in the case of raw materials, LLT with a retention period of 3 months after production was $0.004 \mathrm{mg} / \mathrm{m}^{2} \mathrm{~h}$, MDF with a retention period of 6 months was $0.015 \mathrm{mg} / \mathrm{m}^{2} \mathrm{~h}$, and $\mathrm{HB}$ was $0.043 \mathrm{mg} / \mathrm{m}^{2} \mathrm{~h}$, confirming that $\mathrm{HB}$ with a more extended retention period showed a higher emission than LLT with a shorter retention period.

Additionally, in the PVC sheet, which was a surface material, 30 days for LLT, 45 days for $\mathrm{MDF}$, and 70 days for $\mathrm{HB}$ were used, and $\mathrm{HB}$ had the most prolonged retention period. $\mathrm{F} / \mathrm{F}$ in Figures 8 and 9 and the surface material of veneer showed the same trend. The emission of $\mathrm{HCHO}$ from the composite material was high in the case where the retention period of raw materials and surface materials was long. It was confirmed that the retention period of raw materials and surface materials was not a factor significantly affecting the amount of formaldehyde emitted from the composite material.

Therefore, the amount of $\mathrm{HCHO}$ emitted from the test piece of the composite material did not clearly show a general tendency and consistent difference depending on the characteristics, such as the degree of contamination, type, and retention period of raw materials and surface materials.

\subsubsection{Emission Characteristics Due to Differences in Retention Period}

$\mathrm{HCHO}$ emission characteristics for specimens with different retention periods after molding of composite material specimens were investigated. Figure 7 shows the amount of $\mathrm{HCHO}$ emitted from the composite material after 14 days of retention after molding for LLT+PVC specimens, eight days for MDF+PVC, and three days for HB+PVC.

It was confirmed that the release of $\mathrm{HCHO}$ was the highest in $\mathrm{HB}+\mathrm{PVC}$, which had the shortest retention period after molding. However, this was the test piece with the most prolonged retention period of raw materials and surface materials, and it was judged that the release of $\mathrm{HCHO}$ from the composite materials was strongly affected by the retention period after molding by applying them rather than the retention period of the raw materials and surface materials. It was confirmed that Figures 8 and 9 showed the same trend.

It can be seen that the composite material test piece applied in this study was a sample of a method using an adhesive during molding, so it can be seen that the adhesive component was related to the $\mathrm{HCHO}$ emission factor. It was analyzed that the retention period after molding dramatically affected the amount of $\mathrm{HCHO}$ emitted from the composite material.

\section{Discussion}

Dubai has the reputation for being a continuously growing city with skyscrapers and mega residential projects. Many new residential projects with poor material, and ventilation choices led Dubai to SBS faster than any other country.

This study was the first study in the Middle East to identify factors and characteristics that affect the emission of hazardous chemicals from wood composite materials such as wood mashrabiya that affect the IAQ at residential projects in Dubai.

Many previous studies on indoor air quality in Dubai set up apartments or villas as units to study on-site measurement and reduction methods for IAQ. However, in this study, the TVOC and HCHO emission factors and characteristics of wood mashrabiya, which have been traditionally used a lot in the Middle East but have not been scientifically measured, were analyzed for the correlation with the retention period of raw materials and surface materials to provide the new standard for indoor air pollutants.

The EPD standard in Dubai was applied to evaluate the emission level of hazardous chemicals for the test pieces used in this study, and it was compared and evaluated with the EPD standard in Dubai [50]. 
EPD does not explicitly stipulate wooden windows [51]. However, since standards for wooden office furniture were established, this chapter evaluated them according to this standard. According to the EPD Small Chamber Act, if HCHO emission after seven days was $0.125 \mathrm{mg} / \mathrm{m}^{2} \mathrm{~h}$ or less, it was considered to meet the standard.

In addition, in regulating the amount of VOC emissions from wood materials, all surfaces of wood materials must be paved to suppress the emission of VOCs [52]. In particular, it was stipulated that the rest, except for the edge, of the wood material should be packed with a sheet composed of a thermosetting resin material such as melamine resin, and the emission amount of VOCs after seven days according to the small chamber method was stipulated to be less than $0.4 \mathrm{mg} / \mathrm{m}^{2} \mathrm{~h}$.

$\mathrm{HCHO}$ was evaluated for $0.125 \mathrm{mg} / \mathrm{m}^{2} \mathrm{~h}$ or less, in this study, and the TVOC emission level was $0.4 \mathrm{mg} / \mathrm{m}^{2} \mathrm{~h}$ or less for nine test pieces. As shown in Table 5, it was found that the evaluation results exceeded the TVOC emission standard only when the PVC sheet was wrapped in LLT, and the remaining eight test pieces were all suitable.

Table 5. Emissions of hazardous substances from long-term storage test pieces of raw materials.

\begin{tabular}{|c|c|c|c|c|}
\hline \multirow{2}{*}{ Name } & \multirow{2}{*}{ Material Composition for Test Piece } & \multicolumn{2}{|c|}{ Emission Intensity $\left(\mathrm{mg} / \mathrm{m}^{2} \mathrm{~h}\right)$} & \multirow{2}{*}{ Evaluation } \\
\hline & & TVOC & НСHO & \\
\hline TP-01 & LLT + Wood Adhesive + PVC & 0.808 & 0.004 & Unsuitable \\
\hline TP-02 & LLT + Wood Adhesive + F/F & 0.112 & 0.015 & Suitable \\
\hline TP-03 & LLT + Wood Adhesive + Veneer & 0.096 & 0.043 & Suitable \\
\hline TP-04 & MDF + Wood Adhesive + PVC & 0.106 & 0.006 & Suitable \\
\hline TP-05 & MDF + Wood Adhesive + F/F & 0.031 & 0.081 & Suitable \\
\hline TP-06 & MDF + Wood Adhesive + Veneer & 0.033 & 0.117 & Suitable \\
\hline TP-07 & HB + Wood Adhesive + PVC & 0.231 & 0.015 & Suitable \\
\hline TP-08 & HB + Wood Adhesive + F/F & 0.043 & 0.026 & Suitable \\
\hline TP-09 & HB + Wood Adhesive + Veneer & 0.036 & 0.033 & Suitable \\
\hline
\end{tabular}

Therefore, it was confirmed that wood materials mainly used for mashrabiya showed a stable emission of harmful substances in the case of raw materials with a shelf life of three months or more, and surface finishing materials of one month or more, i.e., with a long storage period.

Results show that the retention period after importing or processing raw materials was the most critical factor. It showed the importance of the grade of raw materials and a certain period of action and sufficient curing in product manufacturing and management.

\section{Conclusions}

In this study, the TVOC and HCHO emission factors and characteristics of wood mashrabiya were analyzed to correlate with the retention period of raw materials and surface materials to provide the new IAQ standard for the Dubai municipality.

In the case of raw and surface materials of mashrabiya with a retention period of 1 month or more, the retention period was the most influential factor for the emission of TVOC. It was confirmed that the longer the retention period of raw materials and surface materials, the smaller the TVOC emission amount. It was required to ensure that raw materials and surface materials had a more extended retention period than a particular amount of time to induce a TVOC decrease.

It was confirmed that the emission of $\mathrm{HCHO}$ from the raw and surface materials of mashrabiya with a retention period of one month or more was significantly affected by the retention period after production and was considered to be influenced by the processing method using the adhesive for molding. 
As a result of evaluating the indoor air emission of the test piece, raw materials with three months or more and surface materials with one month or more should be used. In the case of indoor mashrabiya, it is essential to secure the retention period of raw and surface materials and enough of a retention period after production.

This study targeted mashrabiya with a relatively long retention period. It was necessary to compare and evaluate the short-term case with a retention period of less than one month to secure the reliability of the above conclusion.

Author Contributions: Conceptualization, C.J. and N.A.Q.; methodology, C.J.; software, C.J.; validation, C.J. and N.A.Q.; formal analysis, N.A.Q.; investigation, N.A.Q.; resources, C.J. and N.A.Q.; data curation, C.J.; writing-original draft preparation, C.J.; writing-review and editing, N.A.Q.; visualization, C.J.; supervision, N.A.Q.; project administration, N.A.Q.; All authors have read and agreed to the published version of the manuscript.

Funding: This research received no external funding.

Institutional Review Board Statement: Not applicable.

Informed Consent Statement: Not applicable.

Data Availability Statement: New data were created or analyzed in this study. Data will be shared upon request and consideration of the authors.

Acknowledgments: The authors would like to express their gratitude to Ajman University for APC support and Healthy and Sustainable Buildings Research Center at Ajman University for providing great research environment.

Conflicts of Interest: The authors declare no conflict of interest.

\section{References}

1. Almusaed, A.; Almssad, A.; Homod, R.Z.; Yitmen, I. Environmental profile on building material passports for hot climates. Sustainability 2020, 12, 3720. [CrossRef]

2. Awad, J.; Jung, C. Evaluating the Indoor Air Quality after Renovation at the Greens in Dubai, United Arab Emirates. Buildings 2021, 11, 353. [CrossRef]

3. Jung, C.; Awad, J. The Improvement of Indoor Air Quality in Residential Buildings in Dubai, UAE. Buildings 2021, 11, 250. [CrossRef]

4. Tsai, W.T. Overview of green building material (GBM) policies and guidelines with relevance to indoor air quality management in Taiwan. Environments 2018, 5, 4. [CrossRef]

5. Emirates GBC. Energy Efficiency Program. 2020. Available online: https://emiratesgbc.org/technical-programs/energyefficiency-program/ (accessed on 12 August 2021).

6. Emirates GBC. Emirates Green Building Council Launches First ‘Technical Guidelines for Retrofitting Existing Buildings' in the UAE. 2015. Available online: https:/ / emiratesgbc.org/press_releases/emirates-green-building-council-launches-first-technicalguidelines-for-retrofitting-existing-buildings-in-the-uae/ (accessed on 14 August 2021).

7. Krarti, M.; Dubey, K. Review analysis of economic and environmental benefits of improving energy efficiency for UAE building stock. Renew. Sustain. Energy Rev. 2018, 82, 14-24. [CrossRef]

8. Ghauri, A.; Hameed, M.; Hughes, A.J.; Nazarinia, M. Numerical Analysis of a Zero Energy Villa in the UAE. In International Sustainable Buildings Symposium; Springer: Berlin/Heidelberg, Germany, 2017; pp. 183-197.

9. Jung, C.; Awad, J. The Analysis of Indoor Air Pollutants Emission from New Apartments at Business Bay in Dubai, UAE. Front. Built Environ. 2021, 7, 765689. [CrossRef]

10. The Nationals Sick Buildings Are Leading to Sick UAE Office Workers, Doctors Say. Available online: https://www. thenationalnews.com/uae/health/sick-buildings-are-leading-to-sick-uae-office-workers-doctors-say-1.175866 (accessed on 16 August 2021).

11. Gulf News. Let's Not Forget Indoor Air Quality as Well. 2020. Available online: https://gulfnews.com/business/analysis/letsnot-forget-indoor-air-quality-as-well-1.1589873286956 (accessed on 3 September 2021).

12. DEWA. Green Building Regulations \& Specifications. 2021. Available online: https://www.dewa.gov.ae/ \{\}/media/Files/ Consultants\%20and\%20Contractors/Green\%20Building/Greenbuilding_Eng.ashx (accessed on 4 September 2021).

13. Mannan, M.; Al-Ghamdi, S.G. Indoor Air Quality in Buildings: A Comprehensive Review on the Factors Influencing Air Pollution in Residential and Commercial Structure. Int. J. Environ. Res. Public Health 2021, 18, 3276. [CrossRef]

14. Joseph, P.; Tretsiakova-McNally, S. Sustainable non-metallic building materials. Sustainability 2010, 2, 400-427. [CrossRef]

15. Karunarathna, M.S.; Smith, R.C. Valorization of lignin as a sustainable component of structural materials and composites. Sustainability 2011, 12, 734. [CrossRef] 
16. Kuys, J.; Al Mahmud, A.; Kuys, B. A Case Study of University-Industry Collaboration for Sustainable Furniture Design. Sustainability 2021, 13, 10915. [CrossRef]

17. Chiesa, G.; Cesari, S.; Garcia, M.; Issa, M.; Li, S. Multisensor IoT platform for optimising IAQ levels in buildings through a smart ventilation system. Sustainability 2019, 11, 5777. [CrossRef]

18. May, N.; Guenther, E.; Haller, P. Environmental indicators for the evaluation of wood products in consideration of site-dependent aspects: A review and integrated approach. Sustainability 2017, 9, 1897. [CrossRef]

19. Piasecki, M.; Kozicki, M.; Firlag, S.; Goljan, A.; Kostyrko, K. The approach of including TVOCs concentration in the indoor environmental quality model (IEQ) —Case studies of BREEAM certified office buildings. Sustainability 2018, 10, 3902. [CrossRef]

20. Son, Y.S.; Lim, B.A.; Park, H.J.; Kim, J.C. Characteristics of volatile organic compounds (VOCs) emitted from building materials to improve indoor air quality: Focused on natural VOCs. Air Qual. Atmos. Health 2013, 6, 737-746. [CrossRef]

21. Salthammer, T.; Schripp, T.; Wientzek, S.; Wensing, M. Impact of operating wood-burning fireplace ovens on indoor air quality. Chemosphere 2014, 103, 205-211. [CrossRef]

22. Yu, C.W.; Kim, J.T. Long-term impact of formaldehyde and VOC emissions from wood-based products on indoor environments, and issues with recycled products. Indoor Built Environ. 2012, 21, 137-149. [CrossRef]

23. Bourmaud, A.; Beaugrand, J.; Shah, D.U.; Placet, V.; Baley, C. Towards the design of high-performance plant fibre composites Prog. Mater. Sci. 2018, 97, 347-408. [CrossRef]

24. Adamová, T.; Hradecký, J.; Pánek, M. Volatile organic compounds (VOCs) from wood and wood-based panels: Methods for Evaluation, Potential Health Risks, and Mitigation. Polymers 2020, 12, 2289. [CrossRef]

25. Ulker, O.C.; Ulker, O.; Hiziroglu, S. Volatile organic compounds (VOCs) emitted from coated furniture units. Coatings 2021, 11, 806. [CrossRef]

26. Richter, M.; Horn, W.; Juritsch, E.; Klinge, A.; Radeljic, L.; Jann, O. Natural Building Materials for Interior Fitting and Refurbishment-What about Indoor Emissions? Materials 2021, 14, 234. [CrossRef]

27. Cao, T.; Shen, J.; Wang, Q.; Li, H.; Xu, C.; Dong, H. Characteristics of VOCs released from plywood in airtight environments Forests 2019, 10, 709. [CrossRef]

28. Qi, Y.; Shen, L.; Zhang, J.; Yao, J.; Lu, R.; Miyakoshi, T. Species and release characteristics of VOCs in furniture coating process. Environ. Pollut. 2019, 245, 810-819. [CrossRef]

29. Xiong, J.; Chen, F.; Sun, L.; Yu, X.; Zhao, J.; Hu, Y.; Wang, Y. Characterization of VOC emissions from composite wood furniture: Parameter determination and simplified model. Build. Environ. 2019, 161, 106237. [CrossRef]

30. Liu, X.; Mason, M.A.; Guo, Z.; Krebs, K.A.; Roache, N.F. Source emission and model evaluation of formaldehyde from composite and solid wood furniture in a full-scale chamber. Atmos. Environ. 2015, 122, 561-568. [CrossRef]

31. El-Kassas, A.M.; Mourad, A.I. Novel fibers preparation technique for manufacturing of rice straw based fiberboards and their characterization. Mater. Des. 2013, 50, 757-765. [CrossRef]

32. EPA Sources of Greenhouse Gas Emissions. Available online: https:/ / www.epa.gov/ghgemissions/sources-greenhouse-gasemissions (accessed on 18 October 2021)

33. Mantanis, G.I.; Athanassiadou, E.T.; Barbu, M.C.; Wijnendaele, K. Adhesive systems used in the European particleboard, MDF and OSB industries. Wood Mater. Sci. Eng. 2018, 13, 104-116. [CrossRef]

34. Dietsch, P.; Tannert, T. Assessing the integrity of glued-laminated timber elements. Constr. Build. Mater. 2015, 101, 1259-1270. [CrossRef]

35. Bekhta, P.; Salca, E.A. Influence of veneer densification on the shear strength and temperature behavior inside the plywood during hot press. Constr. Build. Mater. 2018, 162, 20-26. [CrossRef]

36. Zerbst, D.; Affronti, E.; Gereke, T.; Buchelt, B.; Clauß, S.; Merklein, M.; Cherif, C. Experimental analysis of the forming behavior of ash wood veneer with nonwoven backings. Eur. J. Wood Prod. 2020, 78, 321-331. [CrossRef]

37. Wang, W.; Zammarano, M.; Shields, J.R.; Knowlton, E.D.; Kim, I.; Gales, J.A.; Li, J. A novel application of silicone-based flame-retardant adhesive in plywood. Constr. Build. Mater. 2018, 189, 448-459. [CrossRef]

38. Petrović, E.K.; Hamer, L.K. Improving the healthiness of sustainable construction: Example of polyvinyl chloride (PVC). Buildings 2018, 8, 28. [CrossRef]

39. Yan, X.; Han, Y.; Yin, T. Synthesis of urea-formaldehyde microcapsule containing fluororesin and its effect on performances of waterborne coatings on wood surface. Polymers 2021, 13, 1674. [CrossRef]

40. Salca, E.A.; Hiziroglu, S. Hardness and Roughness of Overlaid Wood Composites Exposed to a High-Humidity Environment. Coatings 2019, 9, 711. [CrossRef]

41. Suethao, S.; Shah, D.U.; Smitthipong, W. Recent progress in processing functionally graded polymer foams. Materials 2020, 13, 4060. [CrossRef]

42. Construction Business News Dubai Hills Vista Project by Emaar and Inspired by Automobili Lamborghini Is Sold Out. Available online: https:/ / www.cbnme.com/news/dubai-hills-vista-project-by-emaar-and-inspired-by-automobili-lamborghini-is-soldout/ (accessed on 20 October 2021)

43. Eltawahni, H.A.; Olabi, A.G.; Benyounis, K.Y. Investigating the $\mathrm{CO}_{2}$ laser cutting parameters of MDF wood composite material. Opt. Laser Technol. 2011, 43, 648-659. [CrossRef]

44. Santaniello, F.; Djupström, L.B.; Ranius, T.; Weslien, J.; Rudolphi, J.; Sonesson, J. Simulated long-term effects of varying tree retention on wood production, dead wood and carbon stock changes. J. Environ. Manag. 2017, 201, 37-44. [CrossRef] 
45. Ramage, M.H.; Burridge, H.; Busse-Wicher, M.; Fereday, G.; Reynolds, T.; Shah, D.U.; Scherman, O. The wood from the trees: The use of timber in construction. Renew. Sustain. Energy Rev. 2017, 68, 333-359. [CrossRef]

46. Bribián, I.Z.; Capilla, A.V.; Usón, A.A. Life cycle assessment of building materials: Comparative analysis of energy and environmental impacts and evaluation of the eco-efficiency improvement potential. Build. Environ. 2011, 46, 1133-1140. [CrossRef]

47. Wi, S.; Park, J.H.; Kim, Y.U.; Kim, S. Evaluation of environmental impact on the formaldehyde emission and flame-retardant performance of thermal insulation materials. J. Hazard. Mater. 2021, 402, 123463. [CrossRef]

48. Liu, Z.; Little, J.C. Materials responsible for formaldehyde and volatile organic compound (VOC) emissions. Toxic. Build. Mater 2012, 17, 76-121.

49. EnviroLink Environmental Product Declaration (EPD Certification). Available online: https://www.envirolink.me/https-wwwenvirolink-me-environmental-product-declarations-epd/ (accessed on 24 October 2021).

50. EnviroLink. Environmental Product Declarations EPD LEED Product Certification. 2021. Available online: https://www. envirolink.me/environmental-product-declarations-epd/ (accessed on 2 November 2021).

51. Takano, A.; Hafner, A.; Linkosalmi, L.; Ott, S.; Hughes, M.; Winter, S. Life cycle assessment of wood construction according to the normative standards. Eur. J. Wood Prod. 2015, 73, 299-312. [CrossRef]

52. Kim, S. Control of formaldehyde and TVOC emission from wood-based flooring composites at various manufacturing processes by surface finishing. J. Hazard. Mater. 2010, 176, 14-19. [CrossRef] 